\title{
The Different Between Newborn's Baby Weight Of Maternal Preeclamsia And Non-Preeclamsia
}

\author{
Sarkiah $^{1 *}$ \\ ${ }^{1}$ Midwifery Academies Sari Mulia Banjarmasin \\ *sarkiah@akbidsarimulia.ac.id \\ Hj. Nur Lathifah ${ }^{1}$ \\ ${ }^{1}$ Midwifery Academies Sari Mulia Banjarmasin \\ Nur_latifah@gmail.com \\ Eka Hadiyaningrum \\ ${ }^{1}$ Midwifery Academies Sari Mulia Banjarmasin \\ Eka.hadiyaningrum@gmail.com
}

\begin{abstract}
The purpose of: Knowing the difference between newborn's baby weight of maternal preeclamsia and non-preeclamsia at DR. H. MOCH. ANSARI SALEH HOSPITAL BANJARMASIN in 2015 Method : Research was comparative study by using analytic observational research with cross sectional. Sampling techniques was using Systematic Random Sampling. Analysis of the test was using the bivariat T Pairing Not in Gaussian data and using the Mann Whitney test when the data was not normal Gaussian, with a confidence level of $95 \%(0.05)$.

The results of the : There was difference between newborn's baby weight of maternity preeclamsia and non-preeclamsia, a newborn birth weight of 268.75 grams and Mann Whitney's Z test score $(-2.989)$ and $\rho=0.003<0.05$

Summary: There was difference between newborn's baby weight of maternal preeclamsia and nonpreeclamsia at DR. H. MOCH. ANSARI SALEH BANJARMASIN HOSPITAL in 2015.

Keywords: preeclampsia, newborn's baby weight.
\end{abstract}

\section{INTRODUCTION}

Preeclampsia is an acute and may cause ante, intra, and postpartum complication with signs of hypertension arising after 20 weeks of pregnancy along with proteinuria. Preeclampsia generally occurs in the third trimester of pregnancy, but may also occur in the second trimester of pregnancy [1]

Preeclampsia may lead complications such as low birth weight (LBW), asphyxia, Intra Uterine Fetal Death (IUFD), premature neonatal death, postpartum hemorrhage, visus impairment, placental abruption, and death $[1,2]$. Zuhrina's research in Suwoyo et al [2] in East Kalimantan, Tarakan Hospital was found that in preeclampsia had 34\% LBW risk, 17\% IUFD, 17\% neonatal asphyxia, 9\% neonatal mortality, and maternal risk such as postnatal bleeding 14\%, Visus disruption, placental abruption, and maternal mortality rate of 1 case $(3 \%)$ each. Ika research results at Suwoyo [3] at dr. Sayidiman Magetan 
Hospital proved that there was a possibility of preeclamptic pregnancy 12.57 times risk of giving birth to LBW. Wahyuni and friends research at dr. Sardjito Yogayakarta Hospital found that the highest occurrence of LBW was to pregnant women with severe preeclampsia (32.3\%). The research conducted by Suwoyo and friends [3] at dr. Hardjono Ponorogo Hospital also proved that there was a correlation between preeclampsia and the incidence of LBW. It is happened because in pregnancy with preeclampsia arteriolar blood vessel spasm goes to vassal tissue, blood pressure may incrise as an effort to oxygenation of tissue including placenta can be fulfilled and by narrowing the lumen arteriola may cause disturbance of blood circulation retroplasenta so that blood supply transported to uterus become less, placenta becomes small and nutrient transferred to the fetus decreases. This condition causes slowing growth of the fetus and the weight of the newborn birth is low as well.

According to the World Health Organization (WHO), the incidence rate of preeclampsia ranges from $0.51 \%-38.4 \%$. In developed countries the incidence rate of preeclampsia ranges from $6-7 \%$ and eclampsia $0.1-0.7 \%$. In developing countries, the incidence of preeclampsia is reported to be $4-18 \%$ [4]. While in Indonesia, the incidence of preeclampsia keeps increasing, from $21.5 \%$ in $2010,27.4 \%$ in $2011,26.9 \%$ in 2012 , to $27.1 \%$ in 2013[5]. The incidence of preeclampsia / eclampsia in South Kalimantan based on Riskesdas within population $<7$ million has 4,161 incidence, $99,86 \%$ percentage. South Kalimantan is become the first of four provinces with $<7$ million population.

Preliminary study conducted by the resercher was on December 16, 2015 at Dr. H. Moch. Ansari Saleh Banjarmasin Hospital. It was selected as a research location because Dr. H. Moch Ansari Saleh Hospital is a type B hospital which became the first reference hospital services from in and out of Banjarmasin area.

Based on data most cases in Dr. $\mathrm{H}$. Moch. Ansari Saleh Hospital, from 2013 to 2015 the case of preeclampsia was the second highest after premature rupture of membranes. The incidence of maternity preeclampsia increased from 2013 to 2015. According to recapitulation report in 2013 at Dr. H. Moch. Ansari Saleh Banjarmasin Hospital, there were 95 maternity preeclampsia from 3,126 deleveries (3.03\%) and LBW were 15 infants from 95 preeclampsia $(15,78 \%)$; in 2014 there were 239 preeclampsia from 5,951 deliveries $(4.01 \%)$ and LBW were 35 infants from 239 the preeclampsia $(14,64 \%)$; in 2015 , there were 256 preeclamsia from 3,204 deliveries $(7.99 \%)$ and LBW were 55 infants from 256 preeclampsia mother (21.48\%).

Based on the data, the percentage of incidence of maternal preeclampsia at Dr. $\mathrm{H}$. Moch. Ansari Saleh Banjarmasin Hospital was high enough, so the researcher was interested to conduct a research entitled "The 
Difference Between Newborns' Baby Weight Of Maternal Preeclamsia And NonPreeclamsia at Dr. H. Moch. Ansari Saleh Banjarmasin Hospital in 2015. "

\section{RESEARCH METHOD}

Design research conducted by the design Research analytic. Research methods with cross sectional, the kind of research that emphasizes time measurement or observation data the dependent and independent variables only once at a time [6].

Variable in the research was an independent variable, preeclampsia. The dependent variable was low birth weight (LBW).

\section{RESULT}

1. Responden Description

\begin{tabular}{|c|c|c|c|c|c|}
\hline \multicolumn{2}{|c|}{ No Age } & \multirow{2}{*}{$\begin{array}{c}\text { Preeclampsia } \\
7\end{array}$} & \multirow{2}{*}{$\begin{array}{c}\text { Persentase } \\
(\%)\end{array}$} & \multirow{2}{*}{$\begin{array}{c}\text { Non- } \\
\text { Preeclamps } \\
\text { ia } \\
9\end{array}$} & \multirow{2}{*}{$\begin{array}{c}\begin{array}{c}\text { Persentage } \\
(\%)\end{array} \\
9,4\end{array}$} \\
\hline 1 & $<20$ & & & & \\
\hline & $20-35$ & 66 & 68,7 & 72 & 75 \\
\hline \multirow[t]{2}{*}{3} & $>35$ & 23 & 23,9 & 15 & 15,6 \\
\hline & Total & 96 & 100 & 96 & 100 \\
\hline
\end{tabular}

Based on table 1, it was found that the distribution of age 20-35 years in both maternal preeclampsia and non- preeclampsia had higher percentage more than the age of $<20$ years and $>35$, which were maternal preeclampsia (68.7\%) and non-maternal preeclampsia $(75 \%)$.

\begin{tabular}{|c|c|c|c|c|c|}
\hline $\mathrm{N}$ & Parity & $\begin{array}{c}\text { Preeclampsi } \\
\text { a }\end{array}$ & $\begin{array}{c}\text { Persentatio } \\
\mathrm{n}(\%)\end{array}$ & $\begin{array}{c}\text { Non- } \\
\text { Preeclampsi }\end{array}$ & $\begin{array}{c}\text { Persentati } \\
\text { on }(\%)\end{array}$ \\
\hline 1 & Primipara & 32 & 33,3 & 36 & 37,5 \\
\hline 2 & Multipara & 62 & 64,6 & 60 & 62,5 \\
\hline 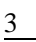 & Grandemulti & 2 & 2,1 & - & - \\
\hline & Total & 96 & 100 & 96 & 100 \\
\hline
\end{tabular}

Based on table 2, the parity of multipara maternal preeclampsia or non-maternal preeclampsia has higher percentage compared to parity in primapara and grandamulti mother which was each percentage of maternal preeclampsia (64.6\%) and nonmaternal preeclampsia $(62.5 \%)$.

c. Newborns' Baby Weight

\begin{tabular}{clcc}
\hline No Newborns' Birth Weight & $\begin{array}{c}\text { Total } \\
(\mathrm{F})\end{array}$ & $\begin{array}{c}\text { Persentati } \\
\text { on }(\%)\end{array}$ \\
\hline 1 & Extremely low, < 1000 gram & - & - \\
2 & Very Low, < 1500 gram & 2 & 1,0 \\
3 & Low, < 2500 gram & 30 & 15,6 \\
4 & Normal, 2.500-4.000 gram & 159 & 82,8 \\
5 & More than, > 4000 gram & 1 & 0,5 \\
\hline & Total & 192 & 100 \\
\hline
\end{tabular}

Based on table 3 , it was found that of 192 samples of the frequency of normal newborns had a higher percentage comparing to low-birth weight of extreme low-birth, Very low, low, and the lowest was 159 infants $(82,8 \%)$.

d. Newborns' Baby Weight of maternasl Preeclampsia and Non Preeclampsia

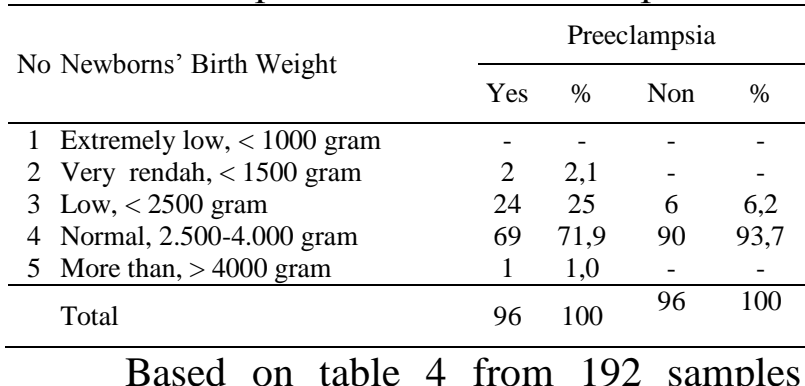

there were 96 maternal preeclamsia and 96 non-maternal preeclamsia, where both of them had normal newborns' baby weight, who had a higher percentage more than the newborn weight of extreme low, very low, low, and the lowest. The maternal preeclamsia is 69 newborns $(71,9 \%)$ and non-maternal preeclampsia is 90 newborns $(93,7 \%)$. 
e. Bivariat Analysis

\begin{tabular}{|c|c|c|c|c|}
\hline \multirow{2}{*}{ No } & \multirow{2}{*}{$\begin{array}{l}\text { Newborns' Birth } \\
\text { Weight maternal }\end{array}$} & \multirow{2}{*}{$\begin{array}{c}\text { Kolmogorrov } \\
\text { Smirnov } \\
(\rho)\end{array}$} & \multicolumn{2}{|c|}{$\begin{array}{c}\text { Mann } \\
\text { Whitney }\end{array}$} \\
\hline & & & $\begin{array}{l}\text { Mean } \\
\text { Rank }\end{array}$ & $\rho$ Value \\
\hline 1 & Preeclampsia & $* 0,002$ & 84,54 & 502 \\
\hline 2 & Non- Preeclampsia & $* 0,139$ & 108,46 & \\
\hline
\end{tabular}

It showed that statistically the average weight of newborns from maternal preeclampsia lower than those whose nonmaternal preeclampsia.

\section{IV.DISCUSSION}

Data analysis used to determine the difference between new borns' baby weight of maternal preeclamsia mother and nonmaternal preeclampsia was parametric Paired $\mathrm{T}$ test analysis, which was previously done by normality test (normal distributed data with value $\rho>0,05)$. The normality test used was Kolmogorov Smirnov test because the number of samples was $>50$. In the normality test for the newborn baby's weight sample from the mathernal preeclampsia is obtained $\rho$ $=0,002(\rho<0,05)$ which means the data is not normal distribution and in the normality test for Sample of newborn baby weight from non maternal preeclampsia is got value $\rho=0,139$ $(\rho>0,05)$ which means data was normal distribution. After the normality test, that was obtained both not normal and normal distribution data, so it could be concluded that both data distributions are not normal so they were not qualify to unpaired $\mathrm{T}$ test then further statistical analysis was done with the
Mann-Whitney test with a confidence level of 95\% and obtained Result of Ranks output $(84,54<108,46)$ so it can be seen that mean value of newborn baby weight from maternal preeclampsia lower than non-maternal preeclampsia. The result of Mann-Whitney test got test value $\mathrm{Z}$ (-2.989) and the value of $\rho=0.003<0.05$ means that there was a difference between new borns' birth weight of maternal preeclamsia and non-maternal preeclamsia at Dr. H. Moch. Ansari Saleh Banjarmasin Hospital in 2015.

The case, according to Kosim [7] states that hypertension in severe preeclampsia will adversely affect fetal health due to the occurrence of severe hypovolemic and strong vasoconstriction of the spiral arteries, resulting in a severe decrease in uteroplacental perfusion. In normal circumstances uteroplacental perfusion serves to support nutrients, oxygen transfer, excretion, and hormone production for fetal growth. So with the decrease of uteroplacental perfusion, it can cause restriction and impaired growth in the fetus. Theoretically this is due to the reduced distribution of glucose and the storage of the liver which will primarily affect the cell size and affect the fetal abdominal circumference, thus representing a diminished liver size or a much lower abdominal circumference. The liver takes about two thirds of the abdominal part. In the fetus with intrauterine growth retardation, the liver shrinks because of depleted glycogen storage. The weight of the 
fetus is thought to be low because the abdomen plays a large role on that value.

Other effects that cause weight differences in infants are due to the onset of preeclampsia that divided into early-onset preeclampsia (before 34 weeks of pregnancy) and late-onset preeclampsia (after 34 weeks ). Early-onset preeclampsia leads to more severe conditions and is a major cause of intrauterine growth restriction comparing to late-onset preeclampsia [10] Based on Ratih's research [11], maternal preeclampsia occurs at earlyonset. It is makes the placental damage that occur earlier in a longer time can cause the LBW. Other studies supporting Irgens $[10,11,12]$ suggest that pregnant women with early-onset preeclampsia have 14 times greater risk of delivering babies weighing $<2000 \mathrm{~g}$ than 3500-3999 g or the probability of women with early-onset preeclampsia causes birth weight $<2000$ g than 3500-3999 $\mathrm{g}$ of $93.3 \%$ (ORs: 13,8-14,2).

Another study that states the corralation between maternal preeclampsia and LBW by Wahyuni [12] at dr. Sardjito Yogyakarta Hospital, showing that there is a significant correlation between severe preeclampsia in pregnant mother and low birth weight (LBW) with $\mathrm{p}=0,045(\mathrm{p}<0,05)$. From the research, it is found that the highest occurrence of LBW was found in pregnant women with severe preeclampsia (32.3\%). Another study supporting this study was a study conducted by Sari (2010) suggesting that women with severe preeclampsia had 7 times greater risk of delivering a baby weighing $<2000 \mathrm{~g}$ than a baby's weight of 3500-3999 $\mathrm{g}$ or it could be stated that the mother's probability severe preeclampsia causes birth weight $<2000 \mathrm{~g}$ more than birth weight $3500-3999 \mathrm{~g}$ by $87.5 \%$ (ORs: 7,0-7,1).

\section{CONCLUSION}

Babies with normal birth weight were $69(43.4 \%)$ from maternal preeclampsia and $90(56.6 \%)$ from non-maternal preeclampsia, 1 newborn (100\%) with more weight birth from maternal preeclampsia , 30 newborns with LBW consist of 24 newborns (80\%) from maternal preeclampsia and 6 newborns (20\%) from non-mathernal preeclampsia, 2 infants $(100 \%)$ with very low birth weight from mathernal preeclampsia.

Mann-Whitney output Ranks results show that the mean value of new borns' birth weight of maternal preeclampsia is lower than that non maternal preeclampsia $(84.54$ $<108.46)$, test value $Z(-2.989)$ and $\rho=0.003$ $<0.05$. It means there is a difference between the newborn's birth weight of maternal preeclampsia and non -maternal preeclampsia at Dr. H. Moch. Ansari Saleh Banjarmasin Hospital in 2015.

\section{REFERENCES}

[1]. Prawirohardjo, Sarwono. 2010. The Science Content. Jakarta: Yayasan Bina Library

[2]. Zuhrina. In: Suwoyo, Antono SD, Triagusanik e. Preeclampsia in pregnancy Relationship with incidence of LOW BIRTH WEIGHT in the 
PROVINCIAL HOSPITAL Dr. Hardjono Ponorogo. Sound health research Forikes journal 2011 Volume II stuff. 25

[3]. Suwoyo, Triagusanik, and SD Antono e. preeclampsia Relationship in pregnancy with the incidence of $L B W$ in the PROVINCIAL HOSPITAL Dr. Hardjono Ponorogo. Sound health research Forikes journal 2011 Volume II stuff. 24-32

[4]. WHO, 2011. Global Status Report on Noncommunicable Diseases 2010. Available from: (http://www.who.int/nmh/publications/n cd_report _ chapter1. pdf, accessed January 13, 2016)

[5]. Data and information centre of the Ministry of health of INDONESIA (InfoDATIN). Figure Preeclampsia Occurrence. Available from: (http://www.depkes.go.id/download.php \%3ffile\%3ddownload/pusdatin/infodatin /infodatin-ibu.pdf\%26

[6]. Nursalam. 2013. The concept and application of we based on science research Nursing. Salemba Jakarta:

[7]. Kosim Yunanto, MS A, Dewi R, et al. Textbook of Neonatology. ED 1. Jakarta: Indonesia, the Pediatrician Bond 2012.

[8]. Faculty Of Medicine Padjajaran University. 2013. Obstetric physiology. Bandung: FK Unpad
[9]. Lim and Kee-Right. Preeclampsia. Harvard Medical School, 2015. Available from: (http://emedicine.medscape.com/article/ 1476919-overview, accessed 13 January 2016), accessed date December 03, 2016

[10]. Rasmussen S, Irgens LM. History of fetal growth restriction is more strongly associated with milder rather than severe pregnancy-induced hypertension. Hypertension. 2010; 51:1233.

[11]. Ratih, Kristanto, Hadisaputro. Relationship of urine albumin levels with weight born babies on preeclampsia weight. Maj. Obstet Ginekol Indones; 2010. Vol 33, No 1.

[12]. Wahyuni, Rachmawati FN. Relationship preeclampsia weight on pregnant women against the LBW was in Dr. Sardjito Yogyakarta year 2010. Pearl Medika 2010; 8 (1): 53. 